\title{
KONSEP DASAR DAN TEKNIK \\ MANAJEMEN RISIKO PERBANKAN SYARIAH
}

\begin{abstract}
Ahdiyat Agus Susila*
Abstract:

Often risks arise because of more than one choice and the impact of each option is not yet known for certain, as uncertain future. There is always an opportunity cost that follows every option taken. Thus, risks may be defined as the consequences of uncertain options that have the potential to lead to unexpected outcomes or other adverse impacts to decision makers. This is the classic definition of risk. From this definition, risk contains several dimensions, namely opportunity costs, potential losses or other negative impacts, uncertainty, and obtaining results that do not match expectations. It is with these demands that risks are measured, mitigated and monitored during the business process.
\end{abstract}

Keywords: Managament, risks,

* Dosen tetap Fak. Ekonomi dan Bisnis Islam INZAH Genggong Kraksaan 


\section{A. Pendahuluan}

Risiko muncul ketika ada kemungkinan lebih dari satu hasil dan hasil akhir tidak diketahui. Risiko dapat didefinisikan sebagai variabilitas atau volatilitas dari hasil yang tak terduga. Hal ini biasanya diukur dengan hasil standar deviasi. Meskipun semua perusahaan menghadapi ketidakpastian. Lembaga keuangan menghadapi beberapa jenis risiko dalam kegiatan yang dilakukannya. Tujuan lembaga keuangan adalah untuk memaksimalkan keuntungan dan nilai tambah pemegang saham dengan menyediakan jasa keuangan yang berbeda terutama dengan mengelola risiko. ${ }^{1}$

Sering kali risiko muncul karena adanya lebih dari satu pilihan dan dampak dari tiap pilihan tersebut belum dapat diketahui dengan pasti, sebagaiamana tidak pastinya masa depan. Selalu ada opportunity cost yang membuntuti setiap pilihan yang diambil. Dengan demikian, risiko bisa didefinisikan sebagai konsekuensi atas pilihan yang mengandung ketidakpastian yang berpotensi mengakibatkan hasil yang tidak diharapkan atau dampak negatif lainnya yang merugikan bagi pengambil keputusan. Inilah definisi klasik dari risiko. Dari definisi tersebut, risiko mengandung beberapa dimensi, yakni biaya peluang, potensi kerugian atau dampak negatif lainnya, ketidakpastian, dan diperolehnya hasil yang tidak sesuai harapan. Dengan berbagai demensi inilah risiko diukur, dimitigasi, dan dimonitor selama proses bisnis berjalan. ${ }^{2}$

\section{B. Pembahasan}

\section{Bentuk-Bentuk Risiko ${ }^{3}$}

Salah satu prasyarat untuk dapat mengelola risiko dengan baik adalah dengan memahami bentuk-bentuk risiko. Risiko dapat diklasifikasikan berdasarkan penyebab terjadinya atau dampak yang ditimbulkannya. Berdasarkan penyebab terjadinya, risiko dibagi menjadi dua, yakni risiko non bisnis dan risiko bisnis. Risiko nonbisnis muncul dari berbagai faktor yang tidak terkait dengan bisnis yang dijalankan, namun dampaknya akan memengaruhi bisnis, seperti kebakaran, banjir, polusi, gempa dan sebagainya. Risiko jenis ini termasuk dalam kelompok risiko murni. Umumnya, bank memitigasi dampak risiko ini dengan mentransfer dan berbagi risiko ke perusahaan asuransi (takaful) atau reasuransi (re-takaful) melalui skema ta'awun. Sedangkan risiko bisnis muncul karena proses bisnis yang dilakukan

${ }^{1}$ Tariqullah Khan, Habib Ahmed, Risk Management: An Analysis of Issues in Islamic Financial Industri (Jeddah: Islamic Development Bank, Islamic Research and Trainning Institute, 2001), hlm. 25

${ }^{2}$ Wahyudi, Miranti K.D., Fenny R., Muhammad B.P., Niken Iwani, Banu M. Haidir, Manajemen Risiko Bank Islam (Jakarta: Salemba Empat, 2013), hlm. 3.

${ }^{3}$ Ibid., hlm. 4. 
bank, seperti kesalahan saat membuat perencanaan, kurangnya informasi saat pengambilan keputusan atau kurang optimalnya pengelolaan aset bank.

Sementara itu berdasarkan dampaknya, risiko dibagi menjadi dua. Pertama, risiko yang dampaknya hanya ditanggung oleh proyek atau bank atau institusi tertentu, terisolasi dan tidak merembet pada proyek atau institusi lain. Risiko ini disebut dengan risiko unik, risiko nonsistematis (unsystematic risk), atau risiko nonsistemis (unsystemic risk). Karena terisolasi, lazimnya risiko ini terjadi akibat faktor-faktor yang hanya ada dan terjadi pada individu bank atau institusi atau proyek tertentu, dan tidak pada selainnya. Dalam membentuk suatu portofolio investasi, untuk meminimalakan total risiko yang dihadapi, berdasarkan prinsip diversifikasi risiko, sering kali risiko unik ini akan menjadi objek risiko yang harus diminimalisasi, dan kerenanya disebut juga risiko yang dapat didiversifikasi (diversified risk). Karena sangat spesifik, risiko ini disebut juga dengan istilah idiosyncratic risk.

Kedua, risiko yang dampaknya menyebabkan terjadinya efek domino, yakni menyeret proyek atau institusi atau sektor atau bahkan negara lain untuk terkena dampak risiko tersebut, atau berdampak pada keseluruhan pasar atau sistem yang ada. Lazimnya, risiko ini muncul sebagai akibat adanya faktor risiko bersama di pasar dan terjadinya hubungan interdependensi antar unit atau institusi atau sektor ekonomi. Faktor risiko ini umumnya terkait dengan variabel makro-ekonomi atau kondisi sektoral atau geografis atau indikator pasar lainnya. Risiko kedua ini disebut dengan risiko pasar. Karena risiko ini berdampak pada semua intitusi atau proyek yang ada dalam cakupan pasar atau sektor geografis tertentu, risiko ini tidak mungkin dapat dihilangkan dengan pendekatan diversifikasi portofolio investasi, kecuali jika keluar dari cakupan tersebut. Karenanya, risiko pasar ini disebut juga dengan risiko yang tidak dapat dideversifikasi (undiversified risk), risiko sistemis (systemic risk), atau risiko sistematis (systematic risk).

Klasifikasi risiko ini dapat ditunjukkan dalam gambar berikut:

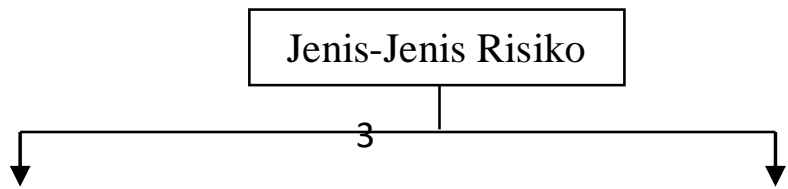

\begin{tabular}{|c|c|}
\hline $\begin{array}{c}\text { Berdasarkan Faktor } \\
\text { Penyebabnya }\end{array}$ & $\begin{array}{c}\text { Berdasarkan } \\
\text { Dampaknva }\end{array}$ \\
\hline
\end{tabular}




\begin{tabular}{|c|c|c|}
\hline Risiko Bisnis & Risiko Unik & Risiko Pasar \\
\hline $\begin{array}{l}\text { Contoh: } \\
\text { (i) risiko } \\
\text { keuangan, yakni } \\
\text { risiko kredit, } \\
\text { risiko pasar, } \\
\text { risiko likuiditas, } \\
\text { risiko } \\
\text { operasional, } \\
\text { risiko imbal } \\
\text { hasil, dan risiko } \\
\text { investasi. } \\
\text { (ii) risiko non } \\
\text { keuangan, yakni } \\
\text { risiko hukum, } \\
\text { risiko reputasi, } \\
\text { risiko strategi, } \\
\text { dan risiko } \\
\text { kepatuhan. }\end{array}$ & $\begin{array}{l}\text { Disebut juga: } \\
\text { risiko non } \\
\text { sistematis } \\
\text { (unsystematic } \\
\text { risk), risiko } \\
\text { yang dapat } \\
\text { didiversifikasi } \\
\text { (diversified } \\
\text { risk). }\end{array}$ & $\begin{array}{l}\text { Disebut juga: } \\
\text { risiko yang } \\
\text { dapat } \\
\text { didiversifikasi } \\
\text { (undiversified } \\
\text { risk), risiko } \\
\text { sistemis } \\
\text { (systemic risk), } \\
\text { risiko } \\
\text { sistematis } \\
\text { (systematic } \\
\text { risk). }\end{array}$ \\
\hline
\end{tabular}

\section{Risiko-Risiko yang Dihadapi Lembaga Keuangan ${ }^{4}$}

\section{a. Risiko Pasar}

Adalah risiko yang berasal dari instrumen dan aset yang diperdagangkan di pasar. Risiko pasar dapat hasil dari sumber makro dan mikro. Risiko pasar sistematis hasil dari pergerakan harga keseluruhan dan kebijakan di perekonomian. Risiko pasar sistematis muncul ketika perubahan harga khusus aset atau instrumen karena terkait dengan instrumen atau aset. Volatilitas harga di berbagai pasar memberikan berbagai jenis risiko pasar. Risiko pasar dapat diklasifikasikan sebagai risiko harga ekuitas, bunga risiko bunga, risiko valuta, dan risiko harga komoditas. Akibatnya, risiko pasar dapat terjadi di kedua perbankan dan buku perdagangan bank. Sementara semua risiko tersebut penting, tingkat suku bunga adalah salah satu risiko utama yang harus khawatirkan oleh bank.

\section{b. Risiko Suku Bunga}

\footnotetext{
${ }^{4}$ Ibid., hlm. 25.
} 
Adalah pemaparan kondisi keuangan bank untuk pergerakan suku bunga. Risiko dapat timbul dari sumber yang berbeda, risiko ini muncul sebagai akibat terjadinya perubahan tingkat suku bunga.

\section{c. Risiko Kredit}

Risiko kredit muncul akibat kegagalan nasabah atau pihak lain dalam memenuhi liabilitas kepada bank Islam sesuai kontrak. Risiko ini disebut juga risiko gagal bayar (default risk), risiko pembiayaan (financing risk), risiko penurunan rating (downgrading risk), dan risiko penyelesaian (settlement risk). Termasuk dalam risiko kredit yaitu risiko konsentrasi pembiayaan.

\section{d. Risiko Likuiditas}

Risiko likuiditas terjadi akibat ketidakmampuan bank Islam dalam memenuhi liabilitas yang jatuh tempo. Untuk memenuhi kebutuhan likuiditasnya, bank dapat menggunakan sumber pendanaan arus kas dan aset likuid berkualitas tinggi yang dapat diagunkan tanpa mengganggu aktivitas dan kondisi keungan bank.

\section{e. Risiko Operasional}

Risiko operasional adalah risiko kerugian yang diakibatkan oleh pengendalian internal yang kurang memadai, kegagalan proses internal, kesalahan manusia (human error), kegagalan sistem, dan/ atau adanya kejadian-kejadian eksternal yang memengaruhi operasional bank. Selain itu, kegagalan memenuhi peraturan, disebut dengan risiko kepatuhan (compliance risk), dan risiko bisnis sering kali dimasukkan dalam kategori risiko operasional.

\section{f. Risiko Hukum}

Risiko hukum muncul akibat adanya tuntutan hukum dan/atau kelemahan aspek yuridis. Risiko ini timbul antara lain karena adanya tuntutan hukum dan ketiadaan peraturan perundang-undangan yang mendukung atau kelemahan perikatan, seperti tidak dipenuhinya syarat sahnya kontrak atau pengikatan agunan yang tidak sempurna. Risiko ini tidak jauh berbeda dengan yang dialami oleh bank konvensional.

\section{Proses Manajemen Risiko}

Manajemen risiko adalah sebuah proses. Sebagai sebuah proses, di dalamnya terdapat berbagai tahapan yang saling berkaitan dan berulang untuk saling melengkapi dan menyempurnakan. Proses manajemen risiko berjalan beriringan dengan proses bank Islam itu sendiri dan menyatu dengan seluruh aktivitas bisnis yang dilakukan oleh bank Islam. 
Tujuan utama dari manajemen risiko adalah untuk memastikan bahwa seluruh kebijakan risiko dan bisnis bisa diimplementasikan secara konsisten. Namun pada praktiknya, proses penerapan manajemen risiko itu sendiri beberapa kali mengalami perubahan orientasi. Praktik manajemen risiko klasik masih berorientasi pada penerapan batas risiko (risk limit) yang konsisten sambil memastikan bahwa kegiatan bisnis tetap menguntungkan. Praktik manajemen risiko modern tidak hanya mencakup penerapan batas risiko konsisten, namun juga menggunakan berbagai ukuran risiko dalam penentuan batas risiko dan menjalankan prinsip risk-adjusment performance pada setiap lini bisnisnya. Jika manajemen risiko klasik, pengelolaan risiko merupakan hal yang terpisah dari kegiatan bisnis perbankan, namun pada manajemen risiko modern, pengelolaan risiko merupakan hal yang koheren dengan proses bisnis perbankan. Risiko merupakan salah satu hal yang menjadi dasar pertimbangan dalam merumuskan kebijaka bisnis perbankan.

Proses manajemen risiko merupakan sebuah sistem yang komprehensif, termasuk di dalamnya menciptakan lingkungan pengelolaan risiko yang tepat, mempertahankan pengukuran risiko yang efisien, proses mitigasi dan monitoring, serta menyusun pengendalian internal yang memadai. Terdapat lima tahap dalam proses manajemen risiko, yaitu identifikasi risiko, pengukuran risiko, mitigasi risiko, monitoring risiko serta pengendalian dan pelaporan risiko. ${ }^{5}$

\section{Proses Identifikasi Risiko}

Merupakan sebuah proses untuk menentukan risiko apa yang dapat terjadi, mengapa risiko tersebut dapat terjadi dan bagaimana risiko itu terjadi. Proses identifikasi risiko harus dilakukan secara menyeluruh. Identifikasi risiko perlu dilakukan secara menyeluruh. Risiko yang melekat pada produk dan aktifitas bank dapat berbeda-beda. Begitu pula dampaknya terhadap keuangan juga berbeda jenis dan jumlahnya. Identifikasi risiko termasuk di dalamnya mendefinisikan perimeter dan jangkauan proses manajemen risiko serta mengidentifikasi seluruh risiko yang potensial, proaktif dalam analisis probabilitas, dan identifikasi kemungkinan mitigasi risikonya jika telah ada.

\section{Pengukuran Risiko}

Pengukuran risiko secara umum terbagi dalam dua kegiatan besar, yakni mendeskripsikan dan menguantifikasi risiko menggunakan probabilitas (pembentukan matriks risiko) serta mengestimasi tingkat signifikansi risiko, batas toleransi bank terhadap risiko, dan analisis biaya-manfaat.

\footnotetext{
${ }^{5}$ Ibid., hlm. 59.
} 
Meskipun proses identifikasi risiko telah dilakukan, menguantifikasi risiko menggunakan probabilitas (membentuk matrik risiko) adalah sebuah tantangan yang harus dilewati sebelum risiko dapat ditukar. Ada beberapa hal yang menyebabkan risiko sulit dikuantifikasi dan diukurt. Pertama, risiko tidak akan terlihat sebelum kejadin kerugian terjadi (even losses). Risiko tidak didefinisikan dalam pernyataan kemungkinan rugi akan tetapi meliputi satuan frekuensi, ukuran, dan besarnya untuk recovery.

Kedua, model manajemen risiko dibutuhkan untuk menguantifikasi risiko. Risiko pada dasarnya merupakan wujud dari ketidakpastian. Oleh karenanya, tidak ada satu usahapun yang dapat memprediksi terjadinya risiko dengan akurasi sempurna. Namun, bukan berarti risiko tidak dapat diukur. Model manajemen risiko digunakan agar risiko dapat diprediksi, diperkirakan, dan diukur sehingga proses pengambilan keputusan dapat berlangsung secara objektif. Ketiga, risiko dalam institusi perbankan sangat berbeda dengan risiko yang dihadapi perusahaan pada umumnya. Walupun ilmu tentang risiko berawal dari pasar modal dan perusahaan umum, namun tidak selurunya dapat diterapkan untuk menangkap berbagai risiko pada institusi perbankan. Hal tersebut disebabkan karena karekteristik bisnis perbankan sangan berbeda dengan perusahaan umum nonkeuangan.

\section{Proses Mitigasi Risiko}

Ketika suatu risiko tejadi, terdapat beberapa kemungkinan respons dan tindakan yang dapat dilakukan untuk menghadapi risiko tersebut. Pertama, bank dapat memutuskan untuk menghindari risiko. Menghindari risiko dipilih sebagai respons terhadap risiko yang dihadapi, di mana bank menganggap biayanya lebih murah dibandingkan harus melakukan tindakan lainnya. Kedua, bank dapat memutuskan untuk mentransfer risiko yang dihadapinya kepada pihak ketiga, seperti perusahaan takaful. Hal ini biasanya terkait dengan risiko murni yang menimbulkan kerugian fisik, seperti kebakaran, kecelakaan kerja, dan lainnya. Ketiga, bank dapat melakukan mitigasi risiko ketika risiko yang dihadapi mustahil untuk dihindari ataupun ditransfer kepada pihak ketiga. Bank tidak mungkin menghindat karena risiko tersebut melekat langsung pada proses bisnis dan sulit ditransfer karena tidak adanya lembaga khusus yang mau menerima jenis risiko tersebut, dan kalaupun ada, biaya yang harus dikeluarkan sangat mahal. Dan keempat, bank bisa membiarkan saja risiko-risiko yang dihadapinya terjadi dan menimbulkan kerugian. Namun, tindakan ini biasanya berlaku untuk jenis risiko tertentu yang dampak kerugiannya sangat rendah dan tidak memengaruhi aktivitas bisnis bank.

\section{Proses Review Risiko}


Dalam proses manajeman risiko, terdapat proses evaluasi risiko setelah analisi risiko dilakukan. Evaluasi risiko merupakan proses yang sangat penting karena akan menentukan langkah dan tindakan yang dapat diambil manajemen untuk mengelola risiko tersebut. Tujuan dilakukannya evaluasi dan review risikoadalah untuk membantu proses pengambilan keputusan, berdasarkan analisis yang didapatkan dari analisis risiko, untuk menentukan berbagai kebijakan terkait perlakuan terhadap risiko dan prioritas pengelolaan risiko yang harus dilakukan.

Pada tahap evaluasi dan review risiko, tingkat risiko aktual yang terjadi pada bank Islam dimonitor dan dibandingkan dengan berbagai ketentuan risiko yang telah ditetapkan sebelumnya, seperti risk tolerance level, risk limit, dan sebagainya. Ketidakcocokan yang terjadi antara kondisi aktual dan kebijakan risiko bisa berarti dua hal. Pertama, terjadinya pelanggaran terhadap kebijakan manajemen risiko. Kedua, kebijakan risiko yang telah ditetapkan sudah out of update sehingga harus direvisi dan disesuaikan dengan perkembangan zaman.

\section{Perangkat Formal dan Struktur Organisasi ${ }^{6}$}

Seperti yang disinggung sebelumnya, manajemen risiko merupakan proses yang berkelanjutan. Karenanya, implementasi manajemen risiko tidak mungkin dapat dilakukan hanya dengan mengandalkan satu orang atau beberapa orang tertentu yang ada di bank. Pada bank yang baru menerapkan manajemen risiko, kebijakan risiko biasanya masih sangat tergantung dari individu tertentu yang ada di dalam bank. Manajemen risiko belum terwujudkan secara formal dalam struktur organisasi, kebijakan, dan budaya bank. Namun, lambat laun, seiring dengan kematangan bank dalam menerapkan manajemen risiko, proses manajemen risiko akan dapat menyatu dengan seluruh aktivitas bank.

Oleh karenanya, untuk memastikan bahwa manajemen risiko dapat berjalan baik, diperlukan serangkain prosedur adminitrasi dan organisasi yang bertujuan untuk mendukung proses implementasi manajemen risiko. Bank Islam harus memiliki kebijakan manajemen risiko, piagam manajemen risiko, standar prosedur operasional, infrastruktur dan proses manajemen risiko. Selain itu, diperlukan adanya satu unit khusus dalam struktur organisasi bank Islam yang ditugaskan untuk menjalankan manajemen risiko dan memantau proses implementasi manajemen risiko pada bank Islam. Bentuk struktur organisasi yang didalamnya telah memasukkan unit pelaksana manajemen risiko adalah sebagai berikut.

\footnotetext{
${ }^{6}$ Ibid., hlm. 75 .
} 
Gambar Struktur Organisasi dengan Unit Risiko

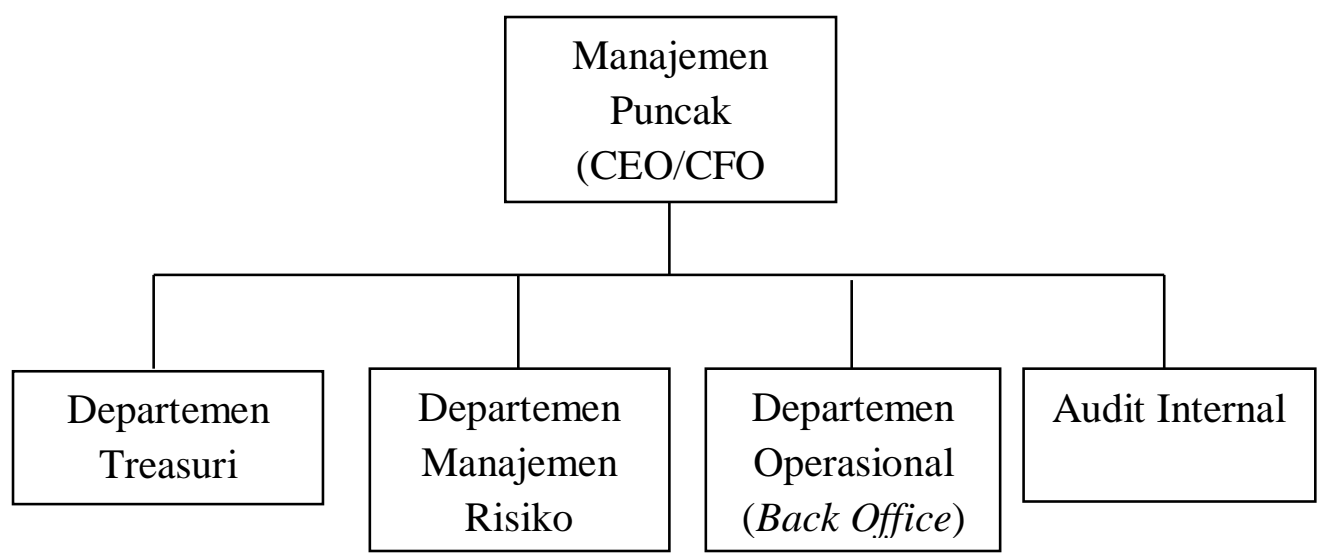

Sumber: P. Jorion, 2003, Financial Risk Management Handbook.

Departemen atau unit manajemen risiko memiliki tanggung jawab untuk memastikan implementasi manajemen risiko secara komprehensif. Namun, kebijakan manajemen risiko tetap menjadi wilayah pengambilan keputusan manajemen puncak dan implementasinya disebarkan secara merata kepada seluruh departemen dan unit bisnis yang ada di struktur organisasi bank Islam.

\section{Kesimpulan}

Risiko muncul ketika ada kemungkinan lebih dari satu hasil dan hasil akhir tidak diketahui. Sering kali risiko muncul karena adanya lebih dari satu pilihan dan dampak dari tiap pilihan tersebut belum dapat diketahui dengan pasti, sebagaiamana tidak pastinya masa depan. Selalu ada opportunity cost yang membuntuti setiap pilihan yang diambil. Dengan demikian, risiko bisa didefinisikan sebagai konsekuensi atas pilihan yang mengandung ketidakpastian yang berpotensi mengakibatkan hasil yang tidak diharapkan atau dampak negatif lainnya yang merugikan bagi pengambil keputusan.

Proses manajemen risiko merupakan sebuah sistem yang komprehensif, termasuk di dalamnya menciptakan lingkungan pengelolaan risiko yang tepat, mempertahankan pengukuran risiko yang efisien, proses mitigasi dan monitoring, serta menyusun pengendalian internal yang memadai.

Tujuan utama dari manajemen risiko adalah untuk memastikan bahwa seluruh kebijakan risiko dan bisnis bisa diimplementasikan secara konsisten. Untuk memastikan bahwa manajemen risiko dapat berjalan baik, diperlukan serangkain prosedur adminitrasi dan organisasi yang bertujuan untuk mendukung proses implementasi manajemen risiko. Bank Islam harus memiliki kebijakan manajemen risiko, piagam manajemen risiko, standar prosedur operasional, infrastruktur dan proses manajemen risiko. 


\section{Daftar Pustaka}

Khan, T. dan Ahmed, H. 2001. Risk Management: An Analysis of Issues in Islamic financial Industri, Jeddah: Islamic Research and Trainning Institute.

Imam Wahyudi, Miranti K.D., Fenny R., Muhammad B.P., Niken Iwani, Banu M. Haidir, 2013 Manajemen Risiko Bank Islam, Jakarta: Salemba Empat. 